\title{
Persepsi Petani Terhadap Metode Tanam Dan Tingkat Keberhasilan Usaha Tani Padi Didesa Rajang Kecamatan Lembang Kabupaten Pinrang
}

\author{
Farmers' Perceptions of Planting Methods and Success Rates of Rice Farming in \\ Rajang Village, Lembang District, Pinrang Regency \\ Cici Paramita $^{1^{*}}$, Nurhapsa $^{1}$, Yusriadi $^{1}$ \\ *Email: ciciparamita358@gmail.com \\ ${ }^{1}$ Fakultas Pertanian, Peternakan dan Perikanan Universitas Muhammadiyah Parepare \\ Diterima: 10 September 2021 / Disetujui: 23 Desember 2021
}

\begin{abstract}
ABSTRAK
Penelitian ini bertujuan 1) Untuk mengetahui bagaimana persepsi petani terhadap metode tanam di Desa Rajang Kecamatan Lembang Kabupaten Pinrang 2) Untuk mengetahui bagaimana tingkat keberhasilan usahatani padi di Desa Rajang Kecamatan Lembang Kabupaten Pinrang penelitian ini dilaksanakan pada bulan september sampai oktober. Teknik pengumpulan data yang digunakan pada penelitian ini adalah statistik des Metode yang digunakan dalam penelitian ini yaitu teknik observasi, wawancara dan kuisioner dan sumber data yang digunakan yaitu data primer dan data sekunder. Analisis data yang digunakan pada penelitian ini adalah statsitik deskriptif dan skala likert. Hasil penelitian menunjukkan bahwa persepsi petani terhadap metode tanam jajar legowo dan tingkat keberhasilan usahatani padi diperoleh nilai 1.172 berada pada kategori (sangat tinggi) dikarenakan indikator pertanyaan yang diajukan yaitu meningkatkan hasil produktivitas mendapatkan respon yang sangat baik/ sangat setuju, sedangkan persepsi petani terhadap metode tanam tradisional memperoleh nilai 885 berada pada kategori ( tinggi) hal ini menunjukkan bahwa persepsi petani terhadap metode tanam tradisional tergolong tidak cukup baik dibandingkan dengan metode tanam jajar legowo yang di anggap memberikan banyak keuntungan dan meningkatkan hasil produksi.
\end{abstract}

Kata Kunci: Persepsi, Petani, Metode Tanam, Tingkat Keberhasilan, Usaha Tani.

\begin{abstract}
This study aims 1) To find out how farmers perception of planting methods in the village of Rajang Lembang District Pinrang 2) To know how the success rate of rice farming in the village of Rajang Lembang District Pinrang this research was conducted in September to October. Data collection techniques used in this study are statistics des Methods used in this study, namely observation techniques, interviews and questionnaires and data sources used i.e. primary data and secondary data. The data analysis used in this study is descriptive statistics and the Likert scale. The results showed that farmers' perception of legowo row planting method and the success rate of rice farming obtained a value of 1,172 is in the category (very high) because the indicators of the question asked are improving productivity results get a very good response/strongly agree, while the perception of farmers to traditional planting methods obtained a value of 885 is in the category ( high) this indicates that the perception of farmers to traditional planting methods is not good enough compared to the method of planting legowo row which is considered to provide a lot of advantages and increase the yield of production.
\end{abstract}

Keywords: Perception, Farmers, Planting Methods, Success Rate, Farming.

(c) () 


\section{A. PENDAHULUAN}

Kabupaten Pinrang adalah salah Satu Daerah Tingkat II (Dua) di Provinsi Sulawesi Selatan Indonesia. Kabupaten ini terletak 185 Km dari Kota Makassar arah utara yang berbatasan dengan Kabupaten Polewali Mandar Provinsi Sulawesi Barat Luas Wilayah 1.961,77 Km2 yang terbagi ke dalam 12 Kecamatan, Meliputi 68 Desa Dan 36 Kelurahan yang terdiri dari 86 Lingkungan dan 189 Dusun.

Upaya peningkatan produksi padi perlu segera dilakukan seiring semakin besarnya kebutuhan masyarakat, hal ini pun sudah dilakukan oleh petani di Desa Rajang. Usaha peningkatan produksi padi sawah salah satunya dilakukan melalui intensifikasi dengan perbaikan teknologi budidaya tanaman padi. Tanaman padi yang terkena sinar matahari akan menghasilkan produksi yang lebih tinggi dan kualitas gabah yang lebih baik. Sistem tanam legowo merupakan rekayasa teknik tanam dengan mengatur jarak tanam antar rumpun maupun antar barisan, sehingga terjadi pemadatan rumpun padi di dalam barisan dan memperlebar jarak antar barisan. Sistem jajar legowo pada dua baris semua rumpun padi berada di barisan pinggir dari pertanaman. Akibatnya semua rumpun padi tersebut memperoleh manfaat dari pengaruh pinggir (border effecct) Kekurangan pangan bisa menyebabkan kerawanan ekonomi, sosial, dan politik yang dapat menggoyahkan stabilitas nasional. Dilain pihak terjadi penurunan lahan sawah akibat alih fungsi Lahan untuk kepentingan non pertanian, dan produksi sawah irigasi cenderung menurun. Rumusan Masalah pada penelitian ini adalah sebagai berikut: 1) Bagaiamana persepsi petani terhadap metode tanam di Desa Rajang, 2) Bagaimana tingkat keberhasilan metode tanam terhadap usahatani padi di Desa Rajang?

\section{B. METODE PENELITIAN}

\section{Tempat dsan Waktu}

Penentuan lokasi penelitian dilakukan selama 2 bulan terhitung mulai bulan September - Oktober 2020 di Desa Rajang Kecamatan Lembang Kabupaten Pinrang, merupakan kawasan yang sangat giat dalam membudidayakan usahatani padi

\section{Populasi dan Sampel}

Menurut Sugiono (2012), mengatakan bahwa populasi adalah keseluruhan penduduk penelitian yang dimaksud untuk diselidiki. Populasi diatasi sebagai jumlah penduduk atau individu yang paling sedikit yang mempunyai sifat yang sama atau homogeny. Menurut Suharsimi Arikunto (2013), populasi adalah keseluruhan dari subjek penelitian populasi merupakan sumber data yang sangat penting karena tanpa kehadiran populasi penelitian tidak akan mungkin terlaksana dari pengertian tersebut populasi dalam penelitian ini yang menjadi populasi adalah para petani yang berjumlah 600 orang petani

Menurut Suharsimi Arikunto (2006) sampel adalah sebagian atau wakil populasi yang diteliti apabila subjek kurang dari 100 lebih baik diambil semua. Sebaliknya jika subjeknya lebih besar dari 100 dapat diambil 
anatara $10 \%-15 \%$ atau $20 \%-25 \%$. Penerikan sampel dari populasi untuk masing-masing kelompok wanita tani dilakukan dengan cara acak sederhana (simple random sampling) agar seluruh petani memiliki peluang yang sama untuk dijadikan sampel mewakili populasinya tanapa membedakan status (Sugiono, 2009). Berdasarkan pendapat diatas penulis mengambil sampel sebesar $10 \%-15 \%$ atau $20 \%-25 \%$ dari jumlah petani 600 orang yang akan menjadi responden penelitian ini sebanyak 60 orang.

\section{Analisis Data}

Analisis data yang digunakan pada penelitian ini statistik deskkriptif dengan menggunakan penegelompokkan, penyebaran, penyederhanaan, serta penyajian data seperti tabel distribusi frekuensi dan pengukuran dengan menggunakan skala likert.

Menurut Ridwan (2008) bahwa skala likert digunakan untuk mengukur sikap, dan pendapat dan persepsi seseorang atau sekelompok tentang kejadian atau gejala sosial. Dengan menggunakan skala likert, maka variabel yang akan diukur dijabarkan menjadi indikator-indikator yang dapat diukur. Kemudian indikator tersebut dijadikan sebagai titik tolak untuk menyusun item-item instrumen yang dapat berupa pernyataan atau pertanyaan. Setiap jawaban dihubungkan dengan bentuk pernyataan atau dukungan persepsi yang diungkapkan dengan kata-kata yang dikategorikan sebagai berikut:

Sangat Setuju (SS) $=5$

Setuju $\quad(\mathrm{S})=4$
Kurang Setuju (KS) $=3$

Tidak Setuju $\quad($ TS $)=2$

Sangat Tidak Setuju $($ STS $)=1$

Menurut Sugiyono (2012) analisis deskriptif adalah statistik yang digunakan untuk menganalisis data dengan cara mendeskripsikan atau menggambarkan data yang telah terkumpul sebagaiamana adanya tanpa bermaksud membuat kesimpulan yang berlaku untuk umum atau generalisasi. Berikut adalah langkah-langkah analisis deskriptif yang digunakan dalam penelitian. Menentukan panjang kelas interval digunakan rumus sebagai berikut:

$\mathrm{P}=$ Rentang/(Banyak Kelas)

Dimana:

$\mathrm{P} \quad=$ Panjang kelas interval

Rentang $=$ Data terbesar - data terkecil

Banyak kelas $=5$

Dilakukan perhitungan dengan memberi nilai/skor pada setiap jawaban pertanyaan yang telah diberikan, dari hasil penjumlahan yang dilakukan maka dapat diperoleh rata-rata Skor untuk menetapkan kriteria penilaian adalah sebagai berikut:

a. Nilai Maksimum didasarkan atas skor jawaban tertinggi dikalikan dengan jumlah responden lalu dikalikan dengan jumlah kuisioner nilai maksimum $=5 \mathrm{x}$ jumlah responden $\mathrm{x}$ jumlah kuisioner.

Nilai Minimum didasarkan atas skor jawaban terendah dikalikan dengan jumlah responden lalu dikalihkan dengan jumlah kuisioner. Nilai minimum $=1 \mathrm{x}$ jumlah responden $\mathrm{x}$ jumlah kuisioner sehinggah 
melalui perhitungan tersebut, dapat diketahui tingkat jawaban responden pada setiap item pertayaan dengan menggunakan garis kontinum. Garis kontinum adalah garis yang digunakan untuk menganalisa, mengukur, dan menunjukan seberapa besar tingkat kekuatan variabel yang sedang diteliti, sesuai instrument yang digunakan.

\section{HASIL DAN PEMBAHASAN}

\section{Pengaruh Metode Tanam Terhadap} Tingkat Keberhasilan Usahatani Padi di

\section{Desa Rajang.}

Dalam usahatani padi penanaman adalah hal yang paling penting dalam rangka menghasilakn produksi yang maksimal. Kegiatan-kegiatan yang akan dijalankan sebelum penanaman dimana menyangkut persiapan lahan, benih, metode tanam yang akan digunakan oleh pelaku usahatani. Serta bagaimana tatacara pelaksanaan program yang diperlukan berdasarkan informasi yang diperoleh.

\section{a. Metode tanam tradisional}

Faktor pendukung dari penggunaan metode tanam tradisional ini yaitu dengan adanya partisipasi dan kemauan dari para pelaku usahatani itu sendiri. Hal ini membuktikan bahwa petani yang berada di Desa Rajang Kecamatan Lembang. Beberapa di antaranya masih menggunakan metode tanam tradisional sebagai cara tanam padi dalam kegiatan usahataninya. Berdasarkan hasil observasi dan wawancara yang telah dilakukan dengan para petani responden pada umumnya mengatakan bahwa. Mereka akan mencoba beralih ke metode tanam yang lebih modern agar hasil produksi gabah bisa meningkat dan proses pengolahan lahan lebih efektif dan tidak memakan waktu yang cukup lama. Mengingat sistem tanam tradisional ini masih memiliki beberapa kelemahan antara lain cara pengolahan tanah yang boros air, penggunaan tenaga kerja dalam jumlah yang banyak, serta memerlukan waktu yang relatif lama dan kurang efisien. Hal ini sesuai dengan pendapat (Pasek dkk, 2005) menyatakan bahwa banyaknya gulma yang tumbuh dan kurangnya pengetahuan petani dalam penanggulangan yang kurang efisien, maka kehadiran gulma tersebut sangat dirasakan memberatkan petani, mengakibatkan penanaman padi tidak berkembang dengan baik.

Tabel 1. Persepsi petani terhadap metode tanam tradisional.

\begin{tabular}{|c|c|c|c|c|c|c|c|c|}
\hline \multirow[b]{2}{*}{ No } & \multirow[b]{2}{*}{ Item Pertanyaan } & \multicolumn{5}{|c|}{ Frekuensi } & \multirow{2}{*}{$\begin{array}{l}\text { Skor } \\
\text { Capaian }\end{array}$} & \multirow[t]{2}{*}{ Ket } \\
\hline & & $\begin{array}{l}1 \\
\text { (RS) }\end{array}$ & $\begin{array}{l}2 \\
(S)\end{array}$ & $\begin{array}{l}3 \\
\text { (R) }\end{array}$ & $\begin{array}{l}4 \\
(\mathbf{T})\end{array}$ & $\begin{array}{l}5 \\
(\mathrm{ST})\end{array}$ & & \\
\hline 1 & $\begin{array}{l}\text { Mempermudah dalam } \\
\text { pengolahn lahan }\end{array}$ & & & & 30 & & 120 & ST: \\
\hline 2 & $\begin{array}{l}\text { Meningkatkan } \\
\text { produktivitas padi }\end{array}$ & & & 1 & 25 & 4 & 123 & $\begin{array}{l}\text { sangat } \\
\text { Tinggi }\end{array}$ \\
\hline 3 & $\begin{array}{l}\text { Butuh tenaga kerja } \\
\text { banyak }\end{array}$ & & & 4 & 25 & & 115 & $\mathrm{~T}$ : Tinggi \\
\hline
\end{tabular}




\begin{tabular}{|c|c|c|c|c|c|}
\hline 4 & $\begin{array}{l}\text { Menghemat biaya } \\
\text { pestisida }\end{array}$ & 10 & 20 & 110 & $\mathrm{~S}$ : sedang \\
\hline 5 & $\begin{array}{l}\text { Menghemat biaya } \\
\text { Pemupukan }\end{array}$ & 14 & 16 & 106 & R: Rendah \\
\hline 6 & $\begin{array}{l}\text { Menekan } \\
\text { serangan } \\
\text { penyakit }\end{array}$ & 13 & 17 & 107 & RS:Rendah \\
\hline 7 & $\begin{array}{l}\text { Tabur benih memudahk } \\
\text { an dalam penanaman }\end{array}$ & 18 & 12 & 102 & sekali \\
\hline 8 & $\begin{array}{l}\text { Membutuhakn benih } \\
\text { yang lebih banyak }\end{array}$ & 18 & 12 & 102 & \\
\hline \multicolumn{2}{|c|}{ Jumlah Total Skor } & & & 885 & \\
\hline
\end{tabular}

Tabel 1 menununjukkan bahwa pengaruh metode tanam tradisional dalam usahatani padi di Desa Rajang. Tergolong tinggi dengan total skor 885 yang berada di antara nilai interval 819 1,011. Hal ini menunjukkan bahwa penggunaan metode tanam tradisional terlaksana dengan baik. Berdasarkan hasil penelitian, menyatakan bahwa item pertanyaan yang menghasilkan skor tinggi di tunjuk pada item pertanyaan (2) dengan skor 123 yaitu meningkatkan produktivitas padi, Hal ini sejalan dengan pendapat (Dewi, 2005) yang menyatakan bahwa tingkat pendidikan dan pengetahuan petani juga akan mempengaruhi pengambilan keputusan dalam kegiatan usahataninya. Petani yang berpendidikan rendah akan merasa kesulitan dalam mengambil keputusan terhadap alokasi sumberdaya yang dimilikinya. Maka secara tidak langsung dalam penerapan keputusan yang tidak tepat dapat mempengaruhi usahatani padi tersebut yang bisa mengakibatkan menurunnnya hasil produksi padi. Proses usahatani berpengaruh terhadap motivasi petani dalam mempertahankan sistem tradisional pada usahataninya. Kemudian untuk item pertanyaan (4) yang menyatakan setuju bahwa metode tanam tradisional dapat menghemat biaya pestisida, dengan skor 110, disusul untuk item pertanyaan ( 1) mendapatkan skor yaitu 120, yang menyatakan setuju bahwa proses penanaman dengan tabur benih langsung memudahkan dalam penanaman. Hal ini sejalan dengan pendapat (Pasek dkk, 2005) yang menyatakan bahwa cara tanam yang baik akan menghasilkan hasil produksi yang maksimal

\section{b. Metode tanam jajar legowo}

Upaya peningkatan produksi baik melalui kegiatan peningkatan produktivitas, telah dilaksanakan antara 
lain melalui penerapan pengelolaan tanaman dan sumberdaya. Tanaman dan sumberdaya terpadu merupakan komponen teknologi yang saling menunjang dan memberikan pengaruh terhadap pertumbuhan dan produktivitas tanaman tanpa merusak lahan dan lingkungan dengan pendekatan inovatif dalam upaya meningkatkan hasil produksi melalui pengelolaan tanaman, tanah, air, hara dan organisme pengganggu tumbuhan (OPT) secara menyeluruh dan berkelanjutan.

Sistem tanam jajar legowo merupakan rekayasa teknik tanam dengan mengatur jarak tanam antar rumpun dan antar barisan sehingga terjadi pemadatan rumpun padi dalam barisan dan melebarkan jarak antar barisan sehingga dapat memperoleh manfaat sebagai tanaman pinggir.

Sistem tanam jajar legowo memberikan ruang tumbuh lebih longgar sekaligus populasi lebih tinggi. Sistem tanam ini juga mampu memberikan sirkulasi udara dan pemanfaatan sinar matahari yang lebih baik untuk pertanaman. Selain itu upaya pengendalian hama dan penyakit serta pemupukan dapat dilakukan dengan lebih mudah. Di Desa Rajang Kecamatan Lembang, Sistem tanam jajar legowo sudah dilaksanakan secara berkelanjutan oleh para petani. Penerapan sistem tanam jajar legowo di Desa Rajang Kecamatan Lembang sudah mencapai 1.172 dan yang belum menerapkan sistem jajar legowo sebesar 885 Berdasarkan hasil wawancara dengan petani. bahwa tingkat keberhasilan usahatani padi dengan menggunakan sistem tanam jajar legowo. Hal ini disebabkan oleh pandangan petani bahwa dalam menerapkan sistem tanam jajar legowo, rumit untuk di laksanakan karena membutuhkan waktu dan tenaga kerja yang terampil sulit, beberapa petani tidak yakin bahwa dalam menerapkan sistem tanam jajar legowo dapat meningkatkan produksi dan tingkat keberhasilan. Sedangkan di beberapa petani mereka merasakan adanya kemudahan dalam melaksanakan budidaya apabila menggunakan sistem tanam jajar legowo terutama pada kegiatan pemeliharaan, serta adanya pengaruh dari seseorang penyuluh dalam penerapan teknologi yang dilaksanakan petani. Hal ini sejalan dengan pernyataan (Hendayana dan Saliem, 2000).

Dari hasil pembahasan pengaruh metode tanam terhadap tingkat keberhasilan usahatani padi. Jika di lakukan secara berkelanjutan dan 
intensif. Maka dapat meningkatkan tingkat produksi dan meningkatkan keberhasilan usahatani padi di Desa Rajang. Menurut Sembiring (2008) keberhasilan peningkatan produksi padi lebih banyak disumbangkan oleh peningkatan produktivitas dibandingkan dengan peningkatan luas panen. Berbeda jarak tanam akan memberikan capaian hasil yang berbeda akibat populasi tanaman yang tidak sama (Abdulrachman et al., 2013). Jarak tanam akan mempengaruhi hasil dengan dua cara, yakni penggunaan jarak tanam yang terlalu rapat, tanaman akan menglami kompetisi dengan tanaman lain di dekatnya. Pemakaian jarak tanam yang terlalu lebar mungkin akan mengurangi hasil per satuan luas, karena jumlah tanamannya menjadi berkurang meskipun ukuran produksi dari masingmasing individu tanaman makin besar. Kerapatan tanaman sangat mempengaruhi pertumbuhan, perkembangan dan hasil padi. Jarak tanam bergantung pada kesuburan tanah, musim, dan Varietas yang ditanam (Sumarno dan Harnoto dalam sulistiani, 2009

Tabel 2. Persepsi petani terhadap metode tanam jajar legowo.

\begin{tabular}{|c|c|c|c|c|c|c|c|c|}
\hline \multirow[b]{2}{*}{ No } & \multirow[b]{2}{*}{ Item Pertanyaan } & \multicolumn{5}{|c|}{ Frekuensi } & \multirow[b]{2}{*}{$\begin{array}{l}\text { Skor } \\
\text { Capaian }\end{array}$} & \multirow[t]{2}{*}{ Ket } \\
\hline & & $\begin{array}{l}1 \\
(\mathrm{RS})\end{array}$ & $\begin{array}{l}2 \\
(T)\end{array}$ & $\begin{array}{l}3 \\
(\mathbf{S})\end{array}$ & $\begin{array}{l}4 \\
(T)\end{array}$ & $\begin{array}{l}5 \\
(\mathrm{ST})\end{array}$ & & \\
\hline 1 & $\begin{array}{l}\text { Dapat meningkatkan } \\
\text { produktivitas }\end{array}$ & & & & 3 & 27 & 147 & ST: \\
\hline 2 & $\begin{array}{l}\text { Mempermudah dalam } \\
\text { pengolahan lahan }\end{array}$ & & & & 2 & 28 & 148 & $\begin{array}{l}\text { sangat } \\
\text { tinggi }\end{array}$ \\
\hline 3 & $\begin{array}{l}\text { Membutuhkan tenaga } \\
\text { kerja yang banyak }\end{array}$ & & & & 2 & 28 & 148 & T:Tinggi \\
\hline 4 & $\begin{array}{l}\text { Menghemat biaya } \\
\text { pestisida }\end{array}$ & & & & 4 & 26 & 146 & S: Sedang \\
\hline 5 & $\begin{array}{l}\text { Menghemat biaya } \\
\text { pemupukan }\end{array}$ & & & & 4 & 26 & 146 & $\mathrm{R}:$ \\
\hline 6 & $\begin{array}{l}\text { Membutuhkan benih } \\
\text { yang lebih sedikit }\end{array}$ & & & & 7 & 23 & 143 & Rendah \\
\hline 7 & $\begin{array}{l}\text { Tabur benih langsung } \\
\text { memudahkan dalam } \\
\text { penanaman }\end{array}$ & & & & 3 & 27 & 147 & $\begin{array}{l}\text { RS: } \\
\text { Rendah } \\
\text { Sekali }\end{array}$ \\
\hline 8 & $\begin{array}{l}\text { Menekan serangan } \\
\text { hama dan penyakit }\end{array}$ & & & & 3 & 27 & 147 & \\
\hline
\end{tabular}

Sumber Data Primer Setelah Diolah, 2021

Tabel 2 menunjukkan bahwa penerapan metode tanam jajar legowo dan hasil memanfaatkan informasi serta arahan dari penyuluh setempat tergolong sangat tinggi dengan total skor 1,172 yang berada di antara nilai interval 1,172 - 885 hal ini menunjukkan 
bahwa penggunaan metode tanam jajar legowo di Desa Rajang terlaksana dengan sangat baik. Berdasarkan hasil penelitian menyatakan bahwa item pertanyaan yang menghasilkan skor tinggi di tunjuk pada item pertanyaan (1) dengan skor 148 yaitu mengatakan setuju bahwa metode tanam jajar legowo dapat meningkatkan hasil produksi, hal ini sejalan dengan pendapat (Zaini, 1996) yang menyatakan bahwa secara ekonomis kelebihan jajar legowo yaitu ditunjukkan dengan hasil produksi yang lebih tinggi 10 - 25 $\%$, disusul dengan item pertanyaan (2) dengan skor 148 yaitu mengatakan setuju bahwa sistem tanam jajar legowo mempermudah dalam pengolahan lahan, kemudian untuk item pertanyaan (3) dengan skor 147 yang mengatakan bahwa sistem jajar legowo merupakan anjuran pemerintah , untuk item pertanyaan (4) dengan skor 147 yaitu setuju bahwa sistem tanam jajar legowo membutuhkan tenaga kerja yang sedikit, hal ini sejalan dengan pendapat (Zaini,1996) yang menyatakan bahwa keunggulan sistem jajar legowo ditunjukkan dengan penghematan tenaga kerja $25-30 \%$. Untuk item pertanyaan (5) dengan skor 148 yaitu mengatakan setuju bahwa penanaman dengan sistem jajar legowo menghemat biaya pemupukan, untuk item pertanyaan (6) dengan skor 148 yaitu mengatakan setuju bahwa sistem jajar legowo membutuhkan benih yang lebih sedikit, untuk item pertanyaan (7) dengan skor 147 yaitu setuju bahwa sistem jajar legowo lebih menguntungkan. Hal tersebut sesuai dengan hasil penelitian (Abidin, Bananiek and Rahardjo, 2013) bahwa keuntungan cara tanam jajar legowo lebih baik dibandingkan dengan cara tanam biasa.

Hasil penelitian ini membuktikan bahwa kesadaran para petani padi yang berada di Desa Rajang dapat dikatakan sangat baik berdasarkan hasil wawancara dengan para petani setelah menerapkan metode tanam jajar legowo perubahan yang paling dirasakan adalah meningkatnya jumlah produksi serta sedikitnya biaya yang digunakan dalam proses pengolahan lahan padi sawah.

Setelah menganalisis berbagai tingkat pengaruh metode tanam jajar legowo dan metode tanam tradsisional, maka rekapitulasi indikator pengaruh metode tanam terhadap terhadap tingkat keberhasilan usahatani padi di Desa Rajang, Kecamatan Lembang, Kabupaten Pinrang dapat dilihat pada tabel 3.

Tabel 3. Rekapitulasi

Pengaruh

Terhadap Tingkat Keberhasilan Usahatani Padi di Desa Rajang Kecamatan Lembang Kabupaten Pinrang

\begin{tabular}{llll}
\hline No. & Sub variabel Pengaruh Metode Tanam & Skor Capaian & Kategori \\
\hline 1. & Metode Tanam Jajar Legowo & 1.172 & Sangat Tiggi \\
2. & Metode Tanam Tradisional & 885 & Tinggi \\
\hline
\end{tabular}

Sumber: Data Primer setelah diolah 2021 
Tabel 3 menunjukkan bahwa nilai pengaruh metode tanam jajar legowo sebanyak 1.172 dengan rentang nilai $1.012-1.204$ tergolong dengan kategori sangat tinggi. Hal ini disebabkan oleh tingginya persepsi petani terhadap indikator pertanyaan Peningakatan jumlah produksi, kemudahan dalam pengolahan lahan, sedikitnya tenaga kerja yang digunakan, biaya yang di keluarkan untuk pemupukan relatif sedikit, serta menguntungkan bagi petani. Yang rata- rata nilai skornya mencapai 147 tertinggi di antara beberapa indikator pertanyaan pengaruh metode tanam terhadap tingkat keberhasilan usahatani padi. Sedangkan pengaruh metode tanam tradisional sebanyak 885 dengan rentang nilai $819-1.011$ tergolong dengan kategori tinggi. Hal ini disebabkan oleh persepsi petani terhadap indikator pertanyaan yang di ajukan yaitu tabur benih langsung memudahkan dalam proses penanaman yang nilai skornya mencapai 102, proses penanaman dengan metode tanam tradisional mengemat biaya pestisida, penanaman dengan metode tradisional mempermudah dalam penanaman dengan nilai skor 62 tertinggi kedua di antara indikator pertanyaan lain. Hal ini pun sejalan dengan penelitian (Suharsimi arikunto dkk, 2009) yang menyatakan bahwa apabila skor jawaban yang diperoleh kurang dari $40 \%$ maka dikategorikan rendah atau kurang baik sedangkan $41-60 \%$ dikategorikan sedang atau cukup baik dan 61 80\% dimasukkan kedalam kategori tinngi, untuk skor yang mencapai $81-100 \%$ dikategorikan dalam kategori sangat tinggi, Maka sesuai dengan hasil yang di peroleh setelah turun langsung ke daerah penelitian dapat di tarik kesimpulan bahwa metode tanam di anggap mampu memberikan pengaruh terhadap persepsi petani dan tingkat keberhasilan usahatani padi di Desa Rajang.

\section{KESIMPULAN DAN SARAN}

Berdasarkan hasil penelitian yang telah dilakukan, maka dapat disimpulkan bahwa persepsi petani terhadap metode tanam jajar legowo yaitu sangat tinggi/sangat baik serta dianggap mampu meningkatkan kebehasilan usahatani padi. Sedangkan persepsi petani terhadap metode tanam tradisional hanya berada pada kategori tinggi/cukup baik dan dianggap belum mampu meningkatkan keberhasilan usahatani padi di Desa Rajang, Kecamatan Lembang Kabpaten Pinrang.

\section{DAFTAR PUSTAKA}

Abdulrachman, S., M. J. Mejaya, N. Agustiani, I Gunawan, P. Sasmita, dan A. Guswara, 2013. Sistem Tanam Legowo. Badan Penelitian dan Pengembangan Pertanian Jakarta.

Dewi, K. R. dan Sudiarti. 2005. Faktor Sosial Ekonomi Yang Mempengaruhi Pengambilan Keputusan Petani Dalam Sistem Penjualan Sayuran. Jurusan Sosial Ekonomi Pertanian Fkultas Pertanian Universitas Udayana ( Tidak Dipublikasikan). Denpasar

Hendayana, R and Saliem H.P. (2000) 'Determinan Adopsi Sistem Tanam Benih Langsung

(TABELA) Dalam Pengkajian SUTPA: Kasus SUTPA di Provinsi Jawa Timur dan Lampung; Jurnal Agro Ekonomi 
Pasek, dkk, 2005. Perbaikan Budidaya Tanaman Padi Sawah Dengan Sistem Tabelatot

(Tanaman Benih Langsung Tanpa Olah Tanah) Di Desa Penatih Kabupaten Badung. Denpasar: Laporan Pengabdian Kepada Masyarakat Universitas Udayana.

Ridwan 2008. Metode Penelitian Survei. LP3ES. Jakarta.

Sembiring, H .2008. Kebijakan Penelitian BB Padi dalam Mendukung Peningkatan Produksi Beras Nasional. Dalam: Prosiding Seminar Apresiasi Hasil Penelitian Padi Menunjang P2BN. Balai Besar Penelitian Tanaman Padi.

Suharsimi Arikunto dan Cepi Safruddin, Evaluasi Program Pendidikan, Jakarta: Bumi Aksara, 2009

Sugiyono 2012. Metode Penelitian Kuantitatif, Kualitatif, dan $R$ dan D, Bandung: CV. Alfabeta

Zaini,.1996. Sistem Usahatani Berbas is Padi dengan Wawasan Agrobisnis. Keragaman Musim Tanam I. Cisarua : Makalah Disampaikan Pada Lokakarya Manajamen Penelitian. Analisis Keragaman, Pengkajian Teknologi SUTPA 